See discussions, stats, and author profiles for this publication at: https://www.researchgate.net/publication/273344907

\title{
Terrestrial radioisotopes as paleoenvironmental proxies in sedimentary formations
}

Article in Journal of Radioanalytical and Nuclear Chemistry · January 2015

Dol: 10.1007/s10967-014-3861-z

CITATIONS

6 authors, including:

Lóránt Bíró

Eötvös Loránd University

23 PUBLICATIONS 114 CITATIONS

SEE PROFILE

Tivadar M. Tóth

University of Szeged

117 PUBLICATIONS 561 CITATIONS

SEE PROFILE
READS

98

Márta Polgári

Hungarian Academy of Sciences

74 PUBLICATIONS 361 CITATIONS

SEE PROFILE

Norbert Kavasi

National Institutes for Quantum and Radiological Science and Technology 55 PUBLICATIONS 571 CITATIONS

SEE PROFILE

Some of the authors of this publication are also working on these related projects:

NIRS President Fund View project

Mineralogy, petrology and geochemistry of Sturtian and Marinoan postglacial transition layers in Otavi Group, NW-Namibia View project 


\title{
Terrestrial radioisotopes as paleoenvironmental proxies in sedimentary formations
}

\author{
Lóránt Bíró · Márta Polgári · Tivadar M. Tóth · \\ Tamás Vigh • Norbert Kávási · Sarata Kumar Sahoo
}

Received: 17 July 2014

(C) Akadémiai Kiadó, Budapest, Hungary 2015

\begin{abstract}
The presence of anomalous terrestrial radioisotopes must be suspected in black shale-hosted manganese ore deposits, based on high organic matter content, which is useful tool in genetic, among them paleoenvironmental investigations. Our work aims at the characterization of the paleoredox conditions of the Úrkút Manganese Formation based on comparison of terrestrial radioisotopes and selected element ratios. Paleoredox indicators were estimated on $\mathrm{U} / \mathrm{Th}, \delta \mathrm{U}, \mathrm{Ni} / \mathrm{Co}, \mathrm{V} / \mathrm{Cr}$, $\mathrm{V} /(\mathrm{V}+\mathrm{Ni})$ and $\mathrm{Ce}^{*}$. The results of paleoredox indicator element ratios show, that these methods must be used with caution (microbial selective element enrichments, mobilizations), and the complex interpretation using mineralogy and microtexture can be recommended.
\end{abstract}

Keywords Úrkút - Manganese ore · Paleoredox proxy · Enrichment factor $\cdot$ Microbial mediation

L. Bíró · T. M. Tóth

Department of Mineralogy, Geochemistry and Petrology, Szeged University, Egyetem str. 2, Szeged 6722, Hungary

e-mail: mtoth@geo.u-szeged.hu

L. Bíró · M. Polgári $(\square)$

Institute for Geology and Geochemistry, Research Center for Astronomy and Geosciences, Hungarian Academy of Sciences, Budaörsi str. 45, Budapest 1112, Hungary

e-mail: rodokrozit@gmail.com

T. Vigh

Mangán Ltd, Külterület 1, Úrkút 8409, Hungary

e-mail: manganvigh@vnet.hu

N. Kávási · S. K. Sahoo

Project for Environmental Dynamics and Radiation Effects, National Institute of Radiological Sciences, 4-9-1, Anagawa, Inage-Ku, Chiba 263-8555, Japan

\section{Introduction}

The Jurassic (Upper Lias) black shale-hosted Úrkút Mn-carbonate deposit (Úrkút Manganese Formation-ÚMF) is a huge deposit with more than $100 \mathrm{Mt}$ of ore reservoirs. Characteristics of the deposit and ore types are summarized by Polgári [1] and Vigh [2]. The two step microbially mediated formation of the ÚMF was also proposed based on complex mineralogical, geochemical and textural interpretations by Polgári [1]. According to the model two cycles of bacterial activity triggered ore formation. Cycle 1 was a near-seabed aerobic chemolithoautotrophic cycle (synsedimentary phase) that was essential in sequestering metal ions $\left(\mathrm{Mn}^{2+}, \mathrm{Fe}^{2+}\right)$ from solution via enzymatic $\mathrm{Mn}$ (II) oxidation. Mn-oxide proto-ore was deposited in the sediment pile, serving as a paleoenvironmental indicator of oxic conditions. Cycle 2 was an anaerobic/suboxic heterotrophic bacterial cycle (diagenetic phase) where early diagenetic bacterially mediated $\mathrm{Mn}$ (IV) and $\mathrm{Mn}$ (III) reduction processes took place via organic matter oxidation and Mn-carbonate mineralization. The ore sequence is laminated at the millimeter scale reflecting a series of Fe-rich biomats by Polgári [3].

The present work is a good example for geochemical results that can be partially attributed to the contribution of biological (microbial) factors. The bio-geochemical relationship between manganese and uranium is for instance versatile, and often difficult to interpret.

Paleoenvironmental characterization on the basis of major- and trace elements, as a further step, is important to get information on ore formation processes, as well as tracing element enrichment and mobilization. Syngenetic paleoenvironmental conditions of the black shale-hosted ÚMF were oxidative, supported by microbial Mn(II) oxidation as main process of sequestration of metal from ore 


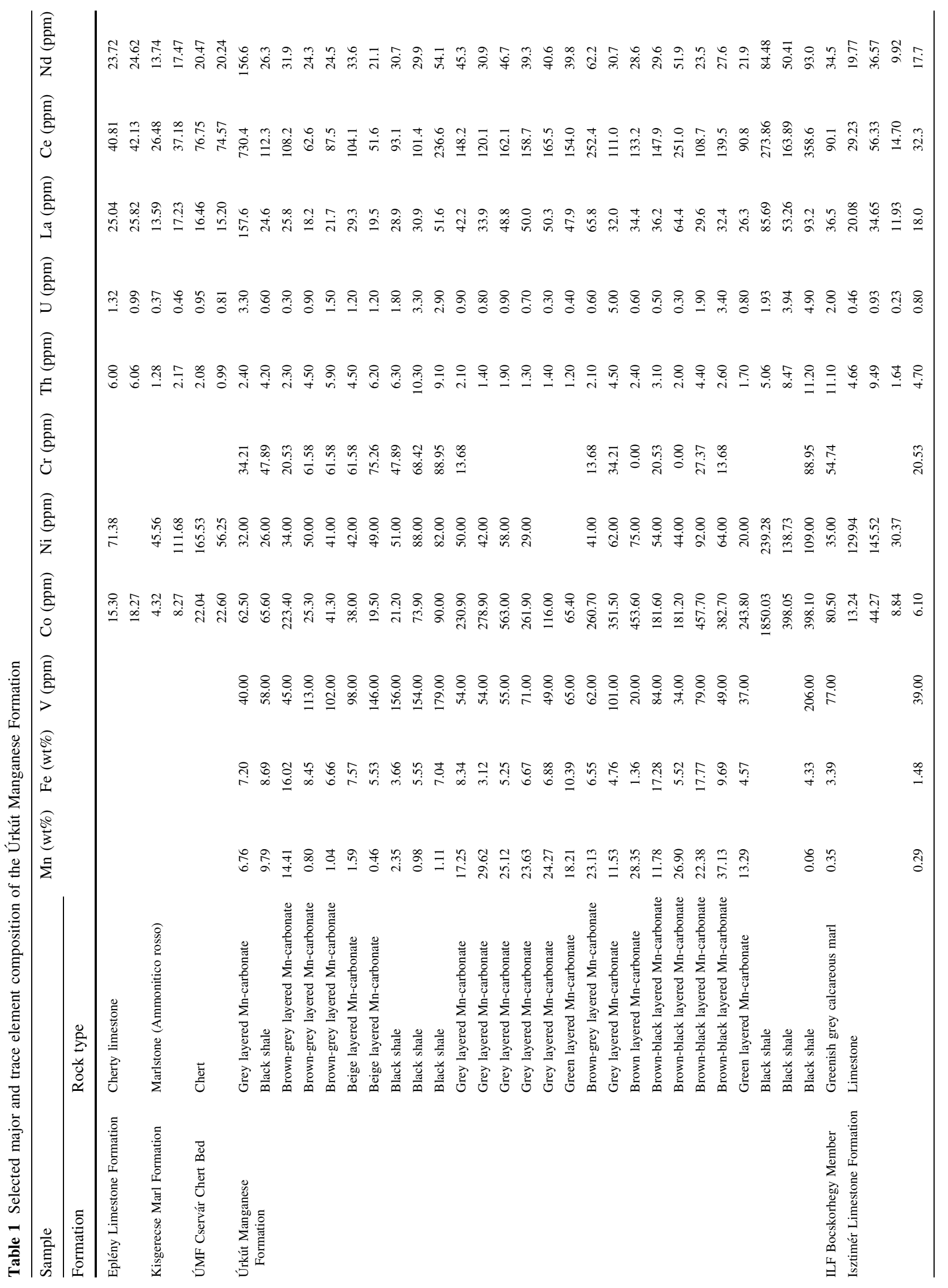


forming fluids, and the organic matter-rich character of the ores is the result of a high productivity and high accumulation rate. This oxidative paleoenvironment is not favourable for primary uranium accumulation, because uranium accumulates in U(IV) form in reducing environments, it can further be oxidized to U(VI). In a sedimentary environment, Eh-pH relations and other factors, such as abundant organic matter, strongly control the possibilities of uranium, and thorium enrichment [1].

Our work investigates the paleoredox conditions of the ÚMF_-including the footwall (Isztimér Limestone Formation Bocskorhegy Member) and the hanging wall (Kisgerecse Marl and Eplény Limestone Formations)_via the comparative examination of $\mathrm{U} / \mathrm{Th}, \delta \mathrm{U}$, rare earth element (REE) patterns, and other trace elements. This offers a case study in comparison with a sedimentary ore formation investigated and interpreted in detail by complex measurements.

\section{Materials and methods}

Total of 39 samples from the whole profile of the black shalehosted manganese ore were investigated for their major, and trace element composition (Table 1). The manganese ore samples $(0.1 \mathrm{~g})$ were decomposed in a microwave digestion system (MLS 1200 Mega, Milestone, Italy) using an acid mixture of $\mathrm{HNO}_{3}, \mathrm{HClO}_{4}$, and $\mathrm{HF}$ (Tama Chemicals Co., Ltd. Japan) and high purity water produced by Milli-Q water purification system (EMD Millipore, Germany).

The main- and trace elements were analyzed using an inductively coupled plasma mass spectrometer instrument, Agilent 7500 (Agilent Technologies, Japan). Before the measurements, standard solutions were prepared from XSTC-1 and XSTC-331 multi-element standard solutions (Spex CertiPrep, USA) at 0, 100, 500, 2500, 5000 ppt to gain calibration curves. Rh standard (1 ppb) was used as an internal standard. To validate the analytical procedure, JLK-1 (Japan) and GBW-07312 (China) certified reference materials were used.

To clarify the paleoredox conditions, indicator patterns were calculated from the original dataset given in Table 1 [4-8]. The amount of authigenic uranium $\left(U_{a}=\delta U\right)$ was calculated after Wignall and Myers [4] according to the following formula, which assumes that the Th has detrital origin in the sedimentary system (accumulating as debris material), and it's average rate related to $\mathrm{U}$ is:

$\mathrm{U}_{\mathrm{det}}=\mathrm{Th} / 3$,

So, the authigenic uranium is:

$\mathrm{U}_{\mathrm{a}}=\mathrm{U}_{\text {total }}-\mathrm{Th} / 3$.

$\mathrm{Ce}^{*}$ was calculated according to the following formula evaluated by Jeans [7]:
$\mathrm{Ce} *_{(\mathrm{PAAS})}=\log \left[3 \mathrm{Ce}_{\mathrm{PAAS}} /\left(2 \mathrm{LaPAAS}+\mathrm{Nd}_{\mathrm{PAAS}}\right)\right]$

Mn* was calculated according to the following formula by Macchour [8]:

\section{$\mathrm{Mn} *=\log \left[\left(\mathrm{Mn} / \mathrm{Mn}_{\mathrm{PAAS}}\right) /\left(\mathrm{Fe} / \mathrm{Fe}_{\mathrm{PAAS}}\right)\right]$; \\ PAAS : Post Archean Average Shale}

Enrichment factors (EF) are routinely used in sedimentary geochemical studies for comparison of major and trace elements (also REE) of the samples to an average composition, in the recent case the Average Shale. Relative enrichment is characterized by $\mathrm{EF}>1$, while relative decrease is characterized by $\mathrm{EF}<1$.

The concentration of an element in sedimentary environments is determined by allochthonous and autochthonous processes. Based on this scenario the so called "not detrital" concentration can also be calculated, which represents the excess concentration in ppm. This excess concentration is the result of a process acted in the sedimentary basin during sediment accumulation or diagenesis after burial. Positive values mean excess of the element, while negative values mean decrease.

Enrichment factor and excess were calculated according to the following formulas:

$$
\begin{aligned}
\text { Enrichment factor }(\mathrm{EF})= & (\text { element } / \mathrm{Al})_{\text {sample }} / \\
& (\text { element } / \mathrm{Al})_{\mathrm{AS}} \\
\text { Excess }(\mathrm{EX})=\text { element }- & \mathrm{Al}_{\text {sample }}(\text { element } / \mathrm{Al})_{\mathrm{AS}} ;
\end{aligned}
$$

AS: Average Shale [9].

\section{Results and discussion}

The enrichment factor and excess data of the studied elements show that only for the $\mathrm{U}$ and $\mathrm{Th}$ it is around zero,

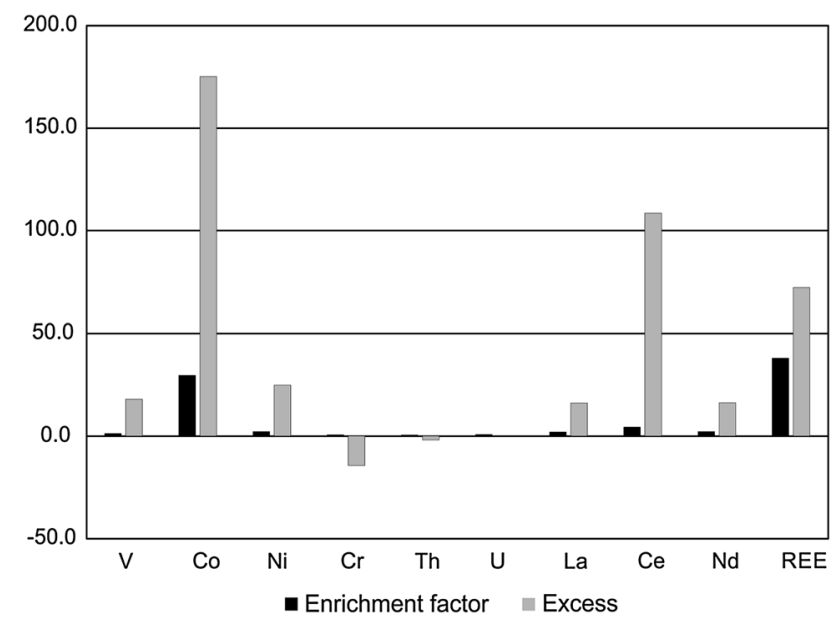

Fig. 1 Enrichment factor and excess (medians in ppm) of the elements 
Table 2 The paleoredox indicators

\begin{tabular}{llll}
\hline Indicator & Oxic & Suboxic & Anoxic \\
\hline Ni/Co [5] & $<5.00$ & $5.00-7.00$ & $>7.00$ \\
V/Cr [5] & $<2.00$ & $2.00-4.25$ & $>4.25$ \\
$\mathrm{~V} /(\mathrm{V}+\mathrm{Ni})[5]$ & $<0.46$ & $0.46-0.60$ & $>0.54$ \\
$\mathrm{U} / \mathrm{Th}[6]$ & $<0.75$ & $0.75-1.25$ & $>1.25$ \\
$\delta \mathrm{U}[4]$ & $<5.00$ & $5.00-12.00$ & 12.00 \\
$\mathrm{Ce}{ }^{*}[7]$ & $<1.00$ & $>1.00$ & \\
$\mathrm{Mn}^{*}[8]$ & $>1.00$ & $<1.00$ & \\
\hline
\end{tabular}

while the others exhibit selective enrichments (Fig. 1). The redox conditions calculated on these elements do not reflect the conditions during ore formation (Table 2). The most enriched elements are cobalt and REE, caused most probably by synsedimentary biogenic (microbial) effects. Cobalt and some REE are microbially active elements (e.g. cerium: Cofactors for e.g. the methanol dehydrogenase of the methanotropic bacterium Methylacidiphilum fumariolicum, manganese oxidizing microbes; cobalt: Active nutrient for bacteria and algae, manganese oxidizing microbes).

Comparison of indicator patterns reflect different paleoredox conditions for the same ore beds. U/Th and $\delta \mathrm{U}$ proxies fit with results of Polgári [10] marked by arrows in Fig. 2, but in the case of black shale horizons the results contradict earlier interpretations, indicating oxic formation conditions. Black shale horizons contain high amounts of organic matter and pyrite originated from microbially mediated sulphate reduction in an anoxic environment, a condition reflected by the prevailing mineralogy. In the

\begin{tabular}{|c|c|c|c|c|c|c|c|}
\hline Formation & Lithology & U/Th & $\delta \mathbf{U}$ & $\mathrm{Ni} / \mathrm{Co}$ & $\mathrm{V} / \mathrm{Cr}$ & $\mathrm{V} /(\mathrm{V}+\mathrm{Ni})$ & $\mathrm{Ce}^{*}$ \\
\hline Eplény Limestone F. & Cherty Limestone & & & & & & \\
\hline Kisgerecse Marl F. & Marlstone (Ammonitico rosso) & & & & & & \\
\hline $\begin{array}{l}\text { ÚMF Cservár Chert } \\
\text { Bed }\end{array}$ & Chert & & & & & & \\
\hline \multirow{27}{*}{ Úrkút Manganese F. } & Grey layered Mn-carbonate & & & & 20 & & \\
\hline & Black shale & & & & & & \\
\hline & Brown-grey layered Mn-carbonate & ace & $\operatorname{coc}$ & $\mathrm{coc}$ & & & \\
\hline & Brown-grey layered Mn-carbonate & ace & $\mathrm{sec}$ & $\mathrm{coc}$ & $\mathrm{ccc}$ & & \\
\hline & Brown-grey layered Mn-carbonate & $\mathrm{ecc}$ & $\mathrm{sec}$ & $\mathrm{coc}$ & $\operatorname{coc}$ & & \\
\hline & Beige layered Mn-carbonate & $\sec$ & $\cos$ & $\cos$ & $\operatorname{coc}$ & & \\
\hline & Beige layered $\mathrm{Mn}$-carbonate & $\sec$ & $\cos$ & $\operatorname{coc} 4$ & $\operatorname{coc}$ & & \\
\hline & Black shale & $\operatorname{coc}$ & coct & $\cos$ & & & \\
\hline & Black shale & 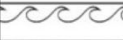 & cocas & cocd & & & \\
\hline & Black shale & $\sec$ & $\operatorname{coc}$ & $\cos$ & & & \\
\hline & Grey layered Mn-carbonate & 200 & $\mathrm{coc}$ & coct & & & \\
\hline & Grey layered Mn-carbonate & $\mathrm{eccc}$ & $\operatorname{coc}$ & $\operatorname{coc}$ & & & \\
\hline & Grey layered Mn-carbonate & $\sec$ & $\operatorname{coc}$ & $\operatorname{coc}$ & & & \\
\hline & Grey-geen layered Mn-carbonate & $20 \mathrm{cos}$ & $\operatorname{coc}$ & क्वि & & & \\
\hline & Grey-geen layered Mn-carbonate & $\mathrm{sec}$ & aced & & & & \\
\hline & Green layered Mn-carbonate & $\sec$ & $\operatorname{coc} \theta$ & & & & \\
\hline & Brown-grey layered Mn-carbonate & acc & $\mathrm{cac}$ & $\mathrm{coc}$ & & & \\
\hline & Grey layered Mn-carbonate & & & & & & \\
\hline & Brown layered Mn-carbonate & $\operatorname{coc}$ & & $\operatorname{coc}$ & & $\cos$ & \\
\hline & Brown-black layered Mn-carbonate & $\operatorname{coc}$ & $\operatorname{coc}$ & $\operatorname{coc}$ & & & \\
\hline & Brown-black layered Mn-carbonate & 200 & $\mathrm{coc}$ & $\operatorname{coc}$ & & 2000 & \\
\hline & Brown-black layered Mn-carbonate & $\operatorname{tac}$ & ceca & $\mathrm{coc}$ & & & \\
\hline & Brown-black layered Mn-carbonate & & & $\mathrm{coc}$ & & & \\
\hline & Green layered Mn-carbonate & poce & & cocd & & & \\
\hline & Footwall black shale & & & & & & \\
\hline & Footwall black shale & & & & & & \\
\hline & Footwall black shale & $\mathrm{ec}$ & & $\mathrm{coc}$ & & & \\
\hline $\begin{array}{l}\text { ILF Bocskorhegy } \\
\text { Member }\end{array}$ & Greenish grey calcareous marl & & & & & & \\
\hline Isztimér Limestone F. & Limestone & $\sec$ & $\cos$ & & $\operatorname{coc}$ & & \\
\hline
\end{tabular}

\begin{tabular}{|c|c|}
\hline & Anoxic \\
\hline & Sub/Dysoxic \\
\hline
\end{tabular}

Fig. 2 Distribution of oxic, suboxic and anoxic conditions along the profile of ÚMF based on selected calculated indicator patterns 
case of grey and brown-black manganese carbonate ore beds, the U/Th and $\delta \mathrm{U}$ proxies more or less support each other and the results of the other paleoredox proxies, concerning the suboxic-anoxic conditions. These interpretations are also supported by the clay mineralogy [10], which indicates the role of diagenesis in the organic matterrich environment, and transport effects observed in the under- or overlying black shale horizons.

\section{Conclusion}

Our project presents results from paleoproductivity evaluation and the analyses of enrichment factors and detrital element quantity comparisons in a microbially mediated manganese ore deposit. Enrichment factors were compared with previous data regarding the utilization of trace elements in biological, microbially mediated sedimentary systems. According to paleoproductivity and enrichment factors, we can assume that biological (microbial) activity played a role in selective element enrichment during the formation of the manganese ore deposit. Uranium and thorium are suitable as paleoredox indicators, but great care has to be taken in the complex interpretation of the data in such microbially mediated systems.

Acknowledgments Lóránt Bíró's research was supported by the European Union and the State of Hungary, co-financed by the European Social Fund in the framework of TÁMOP 4.2.4. A/2-11-12012-0001 'National Excellence Program'.

\section{References}

1. Polgári M, Hein JR, Fórizs I, Vigh T, Szabó-Drubina M, Bíró L, Müller A, Tóth AL (2012) Microbial processes and the origin of the Úrkút manganese deposit, Hungary. Ore Geol Rev 47:87-109

2. Vigh T, Kovács T, Somlai J, Kávási N, Polgári M, Bíró L (2013) Terrestrial radioisotopes in black shale hosted Mn-carbonate deposit (Úrkút, Hungary). Acta Geophys 61(4):831-847

3. Polgári M, Hein JR, Tóth AL, Pál-Molnár E, Vigh T, Bíró L, Fintor K (2012) Microbial action formed Jurassic Mn-carbonate ore deposit in only few hundred years (Úrkút, Hungary). Geology 40(10):903-906

4. Wignall PB, Myers KJ (1988) Interpreting the benthic oxygen levels in mudrocks: a new approach. Geology 16:452-455

5. Rimmer S (2004) Geochemical paleoredox indicators in Devonian-Mississippian black shales, Central Appalachian Basin (USA). Chem Geol 206:373-391

6. Yang B, Hu B, Bao Z, Zhang Z (2011) REE geochemical characteristics and depositional environment of the black shale-hosted Baiguoyuan Ag-V deposit in Xingshan, Hubei Province, China. J Rare Earths 29(5):499-506

7. Jeans CV, Wray DS, Merriman RJ, Fisher MJ (2000) Volcanogenic clays in Jurassic and Cretaceous strata of England and the North Sea Basin. Clay Miner 35:25-55

8. Macchour L, Philip J, Oudin JL (1994) Formation of laminite deposits in anaerobic-dysaerobic marine environments. Mar Geol 117:287-302

9. Wedepohl KH (1971) Environmental influences on the chemical composition of shales and clays. In: Press F, Runcorn SK, Urey HC, Ahrens LH (eds) Physics and chemistry of the earth. Pergamon, Oxford

10. Polgári M, Hein JR, Németh T, Pál-Molnár E, Vigh T (2013) Celadonite and smectite formation in the Úrkút Mn-carbonate ore deposit (Hungary). Sediment Geol 294:157-163 